\title{
SWEET SINDROMAS: KLASIFIKACIJA, DIAGNOSTIKA IR GYDYMAS
}

\author{
Ligita Pilkytė, Edita Gasiūnienė \\ Lietuvos sveikatos mokslu universitetas
}

Raktažodžiai: Sweet sindromas, karštinè neutrofilinė dermatozè, paraneoplastinis sindromas.

\section{Santrauka}

Tyrimo tikslas - atlikti 2007-2021 metais išspausdintu mokslinių šaltinių apie Sweet sindromą analizę, apibendrinti klinikos ypatumus, diagnostiką ir gydymą.

Atlikta mokslinès literatūros apžvalga. Duomenys rinkti iš PubMed, Science Direct, UpToDate duomenų bazių. I sisteminę apžvalgą įtrauktos 2007-2021 metų publikacijos, kuriose aprašomas Sweet sindromas.

Rezultatai. Sweet sindromas arba karštinè neutrofilinè dermatozè pirmą kartą apibūdinta 1964 metais. Tai reta uždegiminè būklè, kuriai būdinga temperatūra, odos bẻrimai ir leukocitozė su neutrofilija. Dažniausiai pasireiškia 30-50 metų moterims. Sweet sindromas gali būti klasikinis, vaistų sukeltas ir paraneoplastinis. Klasikinis Sweet sindromas susijęs su uždegiminėmis ligomis. Vaistų sukeltas pasireiškia vartojant granuliocitų kolonijas skatinančius veiksnius, o paraneoplastinis dažniausiai būna kartu sergant ūmine mieloidine leukemija. Diagnozuojama remiantis A. von den Driesch diagnostikos kriterijais. Karštinè neutrofilinè dermatozè ịprastai gydoma sisteminiais gliukokortikoidais.

\section{Ivadas}

Karštinę neutrofilinę dermatozę, dar kitaip žinomą kaip Sweet sindromas, pirmą kartą aprašè britų dermatologas Robert Douglas Sweet 1964 metais. Tai reta uždegiminè odos liga, kuriai būdinga neutrofilų infiltracija dermoje [1]. Sweet sindromo patogenezė nèra galutinai išaiškinta. Labiausiai paplitusi teorija teigia, kad padidejusio jautrumo reakcijos, citokinų reguliacijos sutrikimai ir genetinis polinkis yra vienos pagrindiniu patologiniu mechanizmo daliu. Esant Sweet sindromui, odoje atsiranda skausmingų uždegiminių papulių, plokštelių ir mazgelių. Dažniausios bẻrimų vietos - galūnès, kaklas ir veidas. Būdingi ir sisteminiai simptomai, tokie kaip galvos ir sąnarių skausmas, bendras silpnumas [2-4].
Tyrimo tikslas - atlikti 2007-2021 metais išspausdintų mokslinių šaltiniu apie Sweet sindromą analizę, apibendrinti klinikos ypatumus, diagnostiką ir gydymą.

\section{Tyrimo medžiaga ir metodai}

Atlikta mokslinès literatūros apžvalga. Duomenys rinkti iš PubMed, Science Direct, UpToDate duomenų bazių. I sisteminę apžvalgą įtrauktos 2007-2021 metų publikacijos, kuriose aprašomas Sweet sindromas.

\section{Tyrimo rezultatai}

Apibrèžtis. Sweet sindromas arba karštinè neutrofilinè dermatozė yra reta uždegiminė būklè, pasireiškianti skausmingais papulonoduliniais odos pažeidimais, karščiavimu, leukocitoze su neutrofilija. Histologiškai būdinga neutrofilinè infiltracija odoje [5]. Sweet sindromas klasifikuojamas i 3 klinikines kategorijas: klasikinis (idiopatinis) siejamas su uždegiminèmis ligomis, vaistų sukeltas ir susijęs su onkologija [6].

Klasifikacija. Klasikinis Sweet sindromas dažniausiai pasireiškia 30-50 metų moterims. Jis dažniausiai siejamas su viršutinių kvépavimo takų infekcijomis, gastroenteritais, uždegiminėmis žarnyno ligomis, něštumu. Klasikinio Sweet sindromo atveju trečdaliui atsiranda dermatozė [7].

Su medikamentais susijęs Sweet sindromas dažniausiai pasireiškia pacientams, kuriems skiriami granuliocitu kolonijas skatinantys veiksniai. Kiti medikamentai, galintys sukelti Sweet sindromą, yra antibiotikai, antihipertenziniai vaistai, antiepileptikai, retinoidai, peroraliniai kontraceptikai [8]. Ligos eiga pagerejja, nutraukus vaisto vartojimą [7].

Nemažai daliai (apie $21 \%$ ) pacientų Sweet sindromas siejamas su onkologine liga. Iš jų dažniausia onkohematologinè liga (85\%) arba solidiniai navikai (15\%), dažniausiai urogenitalinès sistemos [9]. Su onkologija susijęs Sweet sindromas labiausiai siejamas su ūmine mieloidine leukemija [10], tačiau jis gali pasireikšti ir kaip paraneoplastinis sindromas, esant kitų hematologinių susirgimų, tokių, kaip mielodisplastinis sindromas, lètinè limfocitinè leukemija, 
ne Hodžkino limfoma ir daugybinè mielominė liga [6]. Kai sindromas siejamas su onkologine liga, klinikiniai simptomai ne visada gali atitikti klasikinio Sweet sindromo simptomus [11].

Diagnostika. W. Su ir H. Liu (1986) pristatė Sweet sindromo diagnostikos kriterijus [12]. Vèliau, 1994 m., A. von den Driesch juos modifikavo. Klasikini Sweet sindromą galima diagnozuoti, kai jo požymiai atitinka 2 didžiuosius ir bent 2 iš 4 mažujų kriterijų [13]. Kriterijai aprašomi 1 lentelëje.

Šie kriterijai turi būti vertinami atidžiai, kadangi, pavyzdžiui, esant onkologinio susirgimo sukeltai neutropenijai, leukocitozès gali ir nebūti [8].

Kliniškai odos bèrimai pasireiškia kaip papulès, mazgeliai ir skausmingos eriteminès plokštelès. Jie būna nuo kelių milimetrų iki kelių centimetrų. Dažniausiai bėrimai atsiranda veide, kakle ir viršutinėse galūnèse. Kai kuriems pacientams padideja pažeistos odos jautrumas arba pasireiškia deginančio pobūdžio skausmas [2,14]. Be odos bėrimų būdingas karščiavimas $>38^{\circ} \mathrm{C}$. Be to, pacientai dažnai skundžiasi artralgijomis, mialgijomis bendru silpnumu, galvos skausmu [2].

Jeigu pacientui ịtariamas Sweet sindromas, ịprastai atliekami tyrimai: bendras kraujo tyrimas, biocheminiai tyrimai, eritrocitų nusėdimo greitis (ENG) ar CRB, šlapimo tyrimas, vaisingo amžiaus moterims - něštumo testas. Jeigu pacientui, turinčiam Sweet sindromą kartu pasireiškia ir anemija ar trombocitopenija, reikia ịtarti hematologinę ligą [4]. Papildomi tyrimai atliekami priklausomai nuo paciento nusiskundimų [2].

Atlikus odos biopsiją, histologiškai būdinga: paviršinėje dermoje ryški edema, tanki neutrofilų infiltracija, leukocito-

1 lentelè. Sweet sindromo diagnostikos kriterijai, modifikuoti pagal A. von den Driesch [13].

\begin{tabular}{|l|}
\hline Didieji kriterijai \\
\hline 1. Skausmingų eriteminių plokštelių ar mazgelių atsiradimas \\
\hline $\begin{array}{l}\text { 2. Histopatologiškai patvirtinta neutrofilų infiltracija odoje be } \\
\text { leukocitoklazinio vaskulito }\end{array}$ \\
\hline Mažieji kriterijai \\
\hline 1. Karščiavimas $>38^{\circ}{ }^{0} \mathrm{C}$ \\
\hline $\begin{array}{l}\text { 2. Simptomai siejami su lydinčiu hematologiniu ar visceraliniu } \\
\text { onkologiniu procesu, uždegimine liga ar néštumu, arba prieš tai } \\
\text { buvusiomis kvėpavimo, virškinimo takų infekcijomis ar vakci- } \\
\text { nacija }\end{array}$ \\
\hline $\begin{array}{l}\text { 3. Teigiamas atsakas ị gydymą sisteminiais gliukokortikoidais } \\
\text { ar kalio jodidu }\end{array}$ \\
\hline $\begin{array}{l}\text { 4. Pakitusios kraujo reikšmės, bent } 3 \text { iš } 4 \text { : eritrocitų nusėdimo } \\
\text { greitis }>20 \mathrm{~mm} / \mathrm{h}, \text { padidėjęs CRB, }>8000 \text { leukocitų arba } \\
>70 \% \text { neutrofilų }\end{array}$ \\
\hline
\end{tabular}

klazija, endotelio patinimas, vaskulito nebuvimas [2].

Gydymas. Negydant bèrimų, Sweet sindromas gali tęstis savaites ar mènesius [7]. Sergant klasikiniu Sweet sindromu, stebimas greitas atsakas i sisteminius kortikosteroidus, iprastai skiriama prednizolono $0,5-1 \mathrm{mg} / \mathrm{kg}$ doze 3-4 sav. Simptomai pradeda regresuoti per 48 val., o odos bėrimai visiškai išnyksta per 1-2 savaites. Jei pabaigus gydymo kursą liga atsinaujina, tęsiamas gydymas prednizolonu 2-3 mèn. mažiausia efektyvia doze 5-20 mg/d [9, 15]. Kalio jodidas taip gali būti vartojamas gydyti ši sindromą, paprastai skiriama $300 \mathrm{mg} \mathrm{3k/d} 2$ sav. Galimos šalutinès reakcijos: skrandžio ar dvylikapirštès žarnos opos, hipotiroidizmas, plaučiu edema ir padidejusio jautrumo reakcijos $[9,15,8]$. Esant paraneoplastiniam Sweet sindromui, svarbiausias yra pagrindinio piktybinio naviko gydymas. Tokiu atveju hematologai ir onkologai rekomenduoja skirti ir gydymą kortikosteroidais [9].

\section{Išvados}

1. Sweet sindromas - reta uždegiminè liga, dažniausia 30-50 metų moterims. Sindromas gali išsivysti sergant infekcinèmis ligomis, vartojant tam tikrus medikamentus ir sergant onkologinėmis ligomis.

2. Sweet sindromas diagnozuojamas remiantis A. von den Driesch diagnostikos kriterijais ir odos biopsija.

3. Pagrindinis gydymo metodas - sisteminiai gliukokortikoidai.

\section{Literatūra}

1. Villarreal-Villarreal CD, Ocampo-Candiani J, Villarreal-Martínez A. Sweet syndrome: A review and update. Actas Dermosifiliogr 2016;107(5):369-78.

https://doi.org/10.1016/j.ad.2015.12.001

2. Merola JF. Sweet syndrome (acute febrile neutrophilic dermatosis): Pathogenesis, clinical manifestations, and diagnosis. UpToDate, 2021.

3. Vashisht P, Bansal P, Goyal A, Hearth Holmes MP. Sweet Syndrome. StatPearls Publishing 2020.

4. Zheng S, Li S, Tang S, Pan Y, Ding Y, Qiao J, et al. Insights into the characteristics of Sweet syndrome in patients with and without hematologic malignancy. Front Med (Lausanne) 2020;7:20.

https://doi.org/10.3389/fmed.2020.00020

5. Mollaeian A, Roudsari H, Talebi E. Sweet's syndrome: A classical presentation of a rare disease. J Investig Med High Impact Case Rep 2019;7:2324709619895164.

https://doi.org/10.1177/2324709619895164

6. Maller B, Bigness A, Moiño D, Greene J. Sweet's syndrome associated with hematological malignancies. Leuk Res 2020;99(106461):106461. 
https://doi.org/10.1016/j.leukres.2020.106461

7. Cohen PR. Sweet's syndrome--a comprehensive review of an acute febrile neutrophilic dermatosis. Orphanet J Rare Dis 2007;2(1):34.

https://doi.org/10.1186/1750-1172-2-34

8. PĂtraŞcu V, Geoloaica LG, Ciurea RN. Recurrent idiopathic Sweet syndrome - case report and literature review. Curr Health Sci J 2020;46(1):90-8.

9. Raza S, Kirkland RS, Patel AA, Shortridge JR, Freter C. Insight into Sweet's syndrome and associated-malignancy: a review of the current literature. Int J Oncol 2013;42(5):1516-22. https://doi.org/10.3892/ijo.2013.1874

10. Rochet NM, Chavan RN, Cappel MA, Wada DA, Gibson LE. Sweet syndrome: clinical presentation, associations, and response to treatment in 77 patients. J Am Acad Dermatol 2013;69(4):557-64.

https://doi.org/10.1016/j.jaad.2013.06.023

11. Kazmi SM, Pemmaraju N, Patel KP, Cohen PR, Daver N, Tran $\mathrm{KM}$, et al. Characteristics of sweet syndrome in patients with acute myeloid leukemia. Clin Lymphoma Myeloma Leuk 2015;15(6):358-63. https://doi.org/10.1016/j.clml.2014.12.009

12. Su WP, Liu HN. Diagnostic criteria for Sweet's syndrome. Cutis 1986;37(3):167-74.

13. Huda SA, Kahlown S, Jilani MH, Alam SH, Riaz S, Vasigh $\mathrm{M}$, et al. The Sweet syndrome as a cutaneous manifestation of Crohn's disease. Proc (Bayl Univ Med Cent) 2020;33(3):395-7. https://doi.org/10.1080/08998280.2020.1753457
14. Cunha DG, Campos-do-Carmo G, Marujo JM, Verardino GC. Paraneoplastic Sweet's syndrome. An Bras Dermatol 2018;93(4):576-8.

https://doi.org/10.1590/abd1806-4841.20187353

15. Merola JF. Sweet syndrome (acute febrile neutrophilic dermatosis): Management and prognosis. UpToDate 2021.

\section{SWEET SYNDROME: \\ CLASSIFICATION, DIAGNOSTIC AND TREATMENT L. Pilkytè, E. Gasiūnienè}

Keywords: Sweet syndrome, febrile neutrophilic dermatosis, paraneoplastic sindrome.

Summary

Sweet syndrome, or febrile neutrophilic dermatosis, was first described in 1964. It is a rare inflammatory condition characterized by fever, skin lesions, and leukocytosis with neutrophilia. It mostly affects women of age 30-50 years. Sweet syndrome is classified: classical, drug-induced, and paraneoplastic Sweet syndrome. Classical Sweet Syndrome has been linked to inflammatory diseases. Drug-induced occurs in patients receiving granulocyte colonystimulating factors, and paraneoplastic is usually associated with acute myeloid leukemia. Diagnosis is based on Von den Driesch diagnostic criteria. Sweet syndrome is usually treated with systemic glucocorticoids.

Correspondence to: ligita.pilkyte@gmail.com

Gauta 2021-05-20 